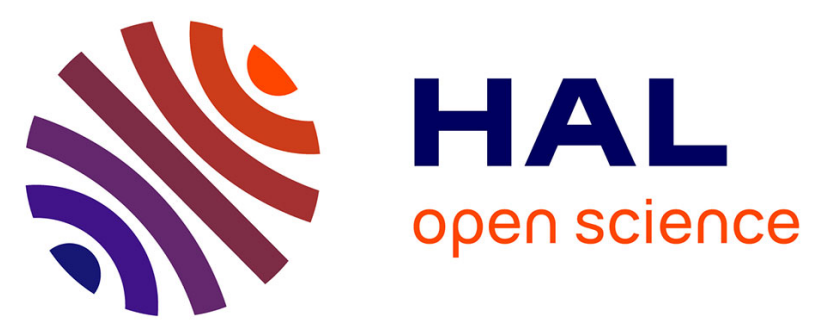

\title{
Understanding Enterprise Architects: Different Enterprise Architect Behavioral Styles
}

\author{
Jaco Du Preez, Alta van Der Merwe, Machdel Matthee
}

\section{To cite this version:}

Jaco Du Preez, Alta van Der Merwe, Machdel Matthee. Understanding Enterprise Architects: Different Enterprise Architect Behavioral Styles. 12th International Conference on Research and Practical Issues of Enterprise Information Systems (CONFENIS), Sep 2018, Poznan, Poland. pp.96-108, 10.1007/978-3-319-99040-8_8. hal-01963054

\section{HAL Id: hal-01963054 \\ https://hal.inria.fr/hal-01963054}

Submitted on 21 Dec 2018

HAL is a multi-disciplinary open access archive for the deposit and dissemination of scientific research documents, whether they are published or not. The documents may come from teaching and research institutions in France or abroad, or from public or private research centers.
L'archive ouverte pluridisciplinaire HAL, est destinée au dépôt et à la diffusion de documents scientifiques de niveau recherche, publiés ou non, émanant des établissements d'enseignement et de recherche français ou étrangers, des laboratoires publics ou privés. 


\title{
Understanding Enterprise Architects: Different Enterprise Architect Behavioural Styles
}

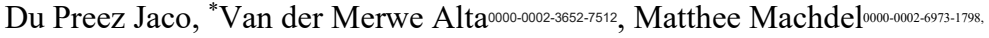 \\ University of Pretoria, Department of Informatics, Pretoria, South Africa \\ jaco.dupreez42@gmail.com, \{alta.vdm, Machdel.matthee\}@up.ac.za,
}

\begin{abstract}
Enterprise Architecture (EA) is an emerging field that focuses on the establishment of a conceptual blueprint that describes the structure and operation of an organization. The purpose is to enable the organization to strategically make decisions on the future state of the organization. Enterprise architects play a key role in the establishment of the EA, even though there are different views of what EA is and how the organization can establish the EA using EA frameworks. In this paper we focused on the different behavioural styles used by enterprise architects in the organization, which enable us to understand the role that EA plays in the organization and shed light on why EA is often executed differently within organizations. Nine behavioural styles are identified by focusing on the roles and competencies of enterprise architects.
\end{abstract}

Keywords: Enterprise architect, Enterprise architect profile, Enterprise Architecture style.

\section{Introduction}

Enterprise architecture (EA) is a relative newly developed discipline where the concepts of EA and Enterprise Architecture Management (EAM) are not universal accepted. There are numerous EA definitions [17] and EA frameworks [5, 19] that evolved over years and in this paper we support the view of Enterprise Architecture as defined by Mentz [16] as an activity that enables, represents, describes, defines and synchronises aspects of the enterprise. Together with the introduction of EA the profession of enterprise architect emerged where the role of the enterprise architect is enhancing the designing and redesigning of the goals and objectives of the enterprise into architected reality thereby promoting proactive enterprise development [25].

As a consequence of the different views on what EA entails, a disagreement about language and terminology exists [22], as well as a lack of clarity in the conceptual foundations of EA [16]. Research on the topic indicated that it is complicated to obtain a unique understanding of EA as a result of the difference in understanding of what EA is [16]. An alternative approach is to understand the enterprise architect and to mitigate the problems of enterprise architects' understanding of EA. To comprehend EA and the enterprise architect, there needs to be a detailed classification of relevant aspects of the enterprise architect. There is a necessity to understand why enterprise architects execute EAM differently, how they go about doing EAM, or what impact it has on EA efficiency and success $[7,23]$. Without an extended classification to understand the different behaviour styles of enterprise architects, there might never be a common 
understanding of why enterprise architects execute EAM differently, how they go about doing EAM, or what impact it has on EA efficiency and success.

From previous work [9] we have identified roles and competencies as two core attributes of the behavioural style of the enterprise architect. In this paper we contribute to the understanding of the complex nature of EA by identifying different behavioural styles of architects, based on their roles and competencies.

The paper is structured by first giving an overview in section 2 of the Enterprise Architect and the role of the Enterprise Architect in EAM. In section 3 we discuss the roles and competencies of the enterprise architect followed by the research design used in the study to establish the different behavioural styles in section 4 .

\section{Enterprise architects}

Enterprise architects are responsible for creating an integrated view of the organisation by performing and executing the EA process. Enterprise architects are also responsible for the management process of documentation, analysis, planning, and enactment of EA or EAM [7]. EAM is seen as a practice to manage and control the rate of change within organisations, thereby reducing the complexity and increasing the efficiency of various aspects of the organization [21]. The performance of EAM is dependent on and influenced by several contextual factors, including factors relating to the architect [13, 21] With so much responsibility on EA practitioners or enterprise architects to produce architecture deliverables, they have the added responsibility to embed EAM within the organisation to guide and support the organisation through its transformation of EA [1].

Different profiles of enterprise architects would take different approaches to implement EA and EAM, which might or might not align with what the organisation requires from them. For any organisation to successfully embed EAM within the organisation, the organisation needs the right architects with the right profiles to improve organisational performance through the embedment of EAM $[1,25]$. The dilemma is not about who is the best architect but about who is the best architect for the organisation within a specific role and competency [25].

Architect roles [2, 20] and architect competencies [6, 24] address behavioural aspects with regards to enterprise architects. The architect role represents the different roles architects can fulfil in their duties as practising enterprise architects, while the architect competency represents the different competencies architects use while assuming a specific architect role. The behavioural styles of architects are fundamental to understanding the enterprise architects as architects execute their respective functions differently.

What is unknown is the understanding of how the context of architect roles and competencies define architect behavioural styles. As both architect EA roles and competency concepts relate to the behaviour of the architect, we argue that an architect behavioural style (a particular way in which something is done, created or performed) can be defined based on the understanding of architect roles and competencies.

\section{Research methodology}

The research conducted was an inductive qualitative study with four distinct phases and different outputs from the different phases (Table 1). 
Table 1. Four phase approach to establish enterprise architect behavioural styles

\begin{tabular}{clll}
\hline Phase & Description & Output & Data collection \\
\hline 1 & Identify Attributes & Attribute set & SLR \\
2 & Identify roles and competencies & Roles and competencies & Literature \\
3 & Define style taxonomy & Matrix & Questionnaire and Literature \\
4 & Define enterprise architect & Description of behavioural & Questionnaire and SLR \\
& behavioural styles & styles & \\
\hline
\end{tabular}

Three components were used in compiling the enterprise behavioural style, namely the enterprise attributes, roles and competencies. The attributes were identified from a systematic literature review (SLR). The roles and competencies were described from literature while the style taxonomy was compiled from the insights into the relationship between roles and competencies. The nine different behavioural styles were identified from the questionnaires as well as the SLR. Finally, the behavioural style description was done by mapping the roles and competencies found in the questionnaire to the attributes.

Systematic literature review: The identification of the architecture attributes was done using a SLR by considering the frequency of a specific term highlighted within current research. The SLR consisted of the three phase approached defined by Mian et. al [18] that consist out of Plan, Execute and Analyse. The guidelines for systematic software engineering SLR as stipulated by Kitchenham [12] was followed that provides information on how to develop your search protocol, how to define the research question, motivate inclusion and exclusion criteria, define the search strategy and extracted data, list the included and excluded studies, use data synthesis guidelines and use the reporting guidelines.

During the planning phase of the SLR, step one was concerned with the correct formulation of the research question, whereas step two involved the precise selection of research sources. The execution phase addressed the criteria for study selection in step three, while step four explored the process for information extraction. In the final phase of analysis, step five guided the researchers on result summarisations. The keywords used during step one in the planning phase of the SLR concentrated around the enterprise architect (solution architect, business architect, information architect, data architect, application architect, technology architect, integration architect) and enterprise architecture (enterprise architectural, EA). Step two described the source list searched on included 13 databases that focus on Information Systems research e.g. ACM Portal, EbscoHost, Scopus and Emerald. Three of the sources were eliminated as it did not meet the quality criteria specified as a requirement for the SLR. Starting with 1305 articles, we proceeded to remove (154) duplicates, (11) non-English articles and (864) articles not satisfying selection criteria, (56) non full-text articles, (164) articles after full text reading and were left with 56 relevant articles. Figure 1 depicts the SLR study process visually while the SLR study selection data is available in Appendix A of the thesis in greater detail [10]. 


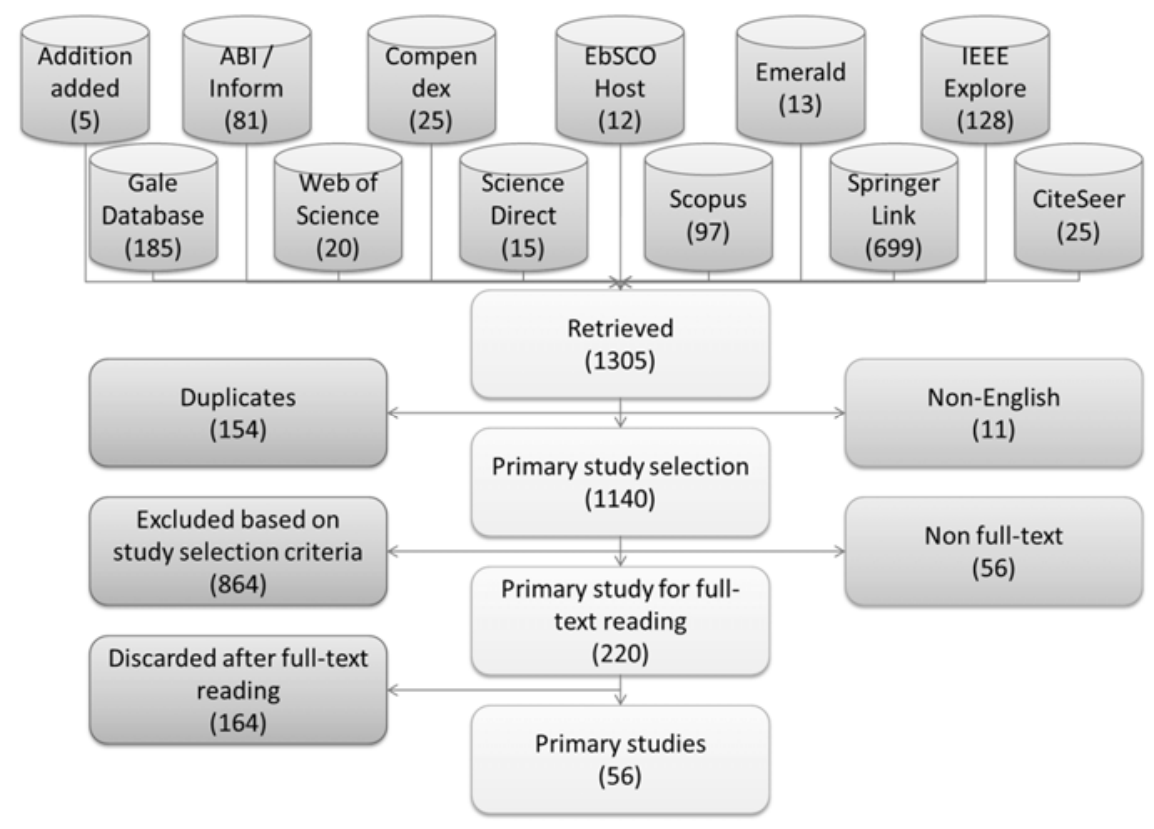

Figure 1: Study selection process

Questionnaire: A self-mediated online questionnaire of 35 questions was developed with the purpose to obtain the understanding of enterprise architects about EA roles and competencies. For the first few questions, each question was aligned to an architect attribute using specific predefined options from secondary sources such as the SLR. The remaining questions were structured on the architects' understanding of their role and the architect competencies required fulfilling their specific role. The complete questionnaire is listed and described within Appendix B of the thesis [10].

Heterogeneous purposeful sampling was used to select a sample of architects. A nonprobability method was selected as it was difficult to obtain the list of the study population, which represented South African organisations actively practising EA. This sampling technique allowed for collected data to describe key themes that were observed. Additionally, understanding the patterns that emerged and how they contributed to the key themes of the research results, enabled the identification of uniqueness. The population sample selection criteria were based on enterprise architects within South African organisations. The selection of the sampling was based on the two-stage heterogeneous sampling process.

During stage one of the heterogeneous sampling processes, a dual approach was taken to publicise the need for participation in the study. This was done by contacting South African organisations, which actively practise EA within their organisation, as well as approaching South African enterprise architects directly via email. Enterprise architects of these South African organisations were then requested to participate in the research study and complete the anonymous questionnaire. As part of stage two, the questionnaire was hosted by a site dedicated to academic research and was available online. Willing participants self-completed the online questionnaire, allowing for data 
to be collected in a consistent manner. There was a total of 131 respondents that initiated the questionnaires where 114 complete questionnaires could be used in the final analysis to determine the architectural behavioural styles. The remaining 17 questionnaires were not completed in full and were therefore excluded.

\section{$4 \quad$ Findings}

The findings of the research is presented in sections 4.1 to 4.4 with regard to the four phases as summarized in Table 1 that the research was conducted in.

\subsection{Phase 1: Identify attributes}

The purpose of the first phase was to identify the EA attributes (a quality or feature that someone has) to be used in later phases when the architectural behavioural styles were defined. A sample table was constructed in Excel with the summary of the 56 articles. A total of 40 EA attributes were identified from the SLR (Table 2). A detailed view of the 56 articles matching the 40 attributes are provided within Appendix A of the thesis [10]

Table 2: EA factors and architect attributes classifications

\begin{tabular}{llll}
\hline Models & Modelling Notation & Competencies & Benefits \\
Certification & Architecture Segment & Discipline & Business objectives \\
Configuration & Profile (Organisation, UML) & Experience & Challenges\& problems \\
Definitions & Purpose & Position Levels & Concerns \\
Deliverables & Scope & Positions & Critical success factors \\
Domains & Standards & Roles & Goals \\
Frameworks & Views & School of thought & Organisational culture \\
Governance & Organisational Segment & Skills Category & Outcomes \\
Maturity stage & Reporting Line & Stakeholders & Politics (Power) \\
Level of detail & Methodologies & Type & Techniques \\
\hline
\end{tabular}

\subsection{Phase 2: Identify roles and competencies}

Enterprise architecture roles: We base our discussion on four of the pertinent writers that wrote on the topic. The first view is that of Akenine [2] that claims that architects fulfil a specific architect role where they then create different architecture artefacts, which are aligned to different levels of creation purpose. A second perspective on architect roles is taken by Gøtze [11], where he describes different behavioural styles of enterprise architects with their distinct roles. He specifies the importance of enterprise architects' understanding of EA scope as the understanding of boundary issues in the EA practice. This understanding of EA scope is also closely related to the work of Lapalme on the EA schools of thought [14]. A third study focuses on the understanding of architect roles and competencies in a proactive enterprise development [20]. The authors believe that a strong relationship exists between the role of enterprise architect and proactive enterprise development as well as a relationship between enterprise architect impact and stakeholder management. Similar to the understanding of EA scope and EA purpose by Lapalme [14], the authors proclaim that the concept of proactivity can be understood in terms of both planning an EA initiative 
and the architects' stakeholders. Lastly, a study by Strano and Rehmani [25] identified several functional enterprise architect roles and described the interfaces with other functional organisational roles. The roles change agent, communicator, leader, manager and modeller were identified and described using the unique value the roles provided as well as the impact of not fulfilling the specific architect roles. In addition the study highlighted the organisational positioning or reporting line of the roles as well as the required competencies for each role to ensure maximum effectiveness of the architect role. The authors continued to state that the understanding of architect roles forms the foundation to support the profession of enterprise architects.

We use the five roles as identified by Strano and Rehmani [25] in our style taxonomy namely change agent, communicator, leader, manager and modeller, as described in Table 3

Table 3: Architect role description [22]

\begin{tabular}{ll}
\hline Role & Description \\
\hline Change agent & As a change agent, the enterprise architect supports enterprise \\
leaders in establishing and promoting the best strategy to \\
accomplish business goals and objectives. \\
As a communicator, the enterprise architect assists managers, \\
analysts, systems architects, and engineers in understanding the \\
details of the strategy sufficiently well to make decisions and \\
execute the plan that leads to realization of the shared vision. \\
As a leader, the enterprise architect participates in creating a shared \\
vision, motivating members of the enterprise to aspire to achieving \\
the vision, and providing clear direction regarding what is required \\
to execute a strategy to accomplish goals and objectives that result \\
in performance improvements. \\
As a manager, the enterprise architect organises the architecture \\
team and ensures that adequate resources are secured to perform the \\
architecture process. \\
As a modeller, the enterprise architect provides a representation of \\
the relationships of enterprise components with sufficient detail and \\
in the format needed to enable making necessary decisions to \\
execute the strategic plan.
\end{tabular}

Enterprise architecture competency: In an executive report Bredemeyer and Malan [6] look at the necessary qualities for great enterprise architects. The report highlight five competency areas, namely technical, leadership, organisational politics, consulting and strategy.

While considering core enterprise architect competencies rather than competency areas, a subsequent study considered enterprise architects within the higher education industry [15]. The study pronounced that with an increasing demand for understanding of EA that it has implications for enterprise architects' expertise [18] Using the practical competence model, the study identifies the seven core competences categories (personal traits, general skills, professional skills, industrial knowledge, project management skills, team management skills and communication and negotiation skills) of enterprise architects in the higher education industry. These core competencies can guide decision-makers on enterprise architect personal development and skills required for success in the EA discipline.

A similar but unrelated study by Steghuis and Proper [24] considered basic competencies, responsibilities, and personality types of enterprise architects. Similar to 
the work of Bredemeyer and Malan [6], and Lu and Lin respectively [15], the authors classified the basic competencies into two distinct competency categories as personal and professional competencies [24], where professional competencies represent three competencies dealing with knowledge, attitude, and skills necessary to perform a role, and personal competencies represent 35 competencies concerned with the influence behind performing a specific role. For the purpose of the style taxonomy the qualities expressed by Bredemeyer and Malan [6], namely technical, leadership, organisational politics, consulting and strategy were used, as described in Table 4.

\section{Table 3: Architect competency description [5]}

\begin{tabular}{ll}
\hline Competency & Description \\
\hline Technical & The enterprise architect must be highly credible within several \\
communities. IT architects must be highly regarded in their \\
technical communities. Further, they and the business architects \\
must have high credibility among senior business managers. This \\
credibility comes from experience and talent. \\
The architect is a leader in different communities. First, there is \\
"leading up" and influencing the strategic direction. The \\
architecture team needs a designated leader who is accepted and \\
followed by the team. An architecture team without leadership \\
thrashes and diverges. \\
The better architects are at working the organisational politics \\
dimension of the role, the more likely they are to be successful. This \\
is not about power but rather about getting things done without \\
direct authority and power. \\
The architect is educator and consultant, solving complex problems \\
with systemic impact and helping implementers understand the \\
architecture and see where what they do affects the architecture. \\
The chief enterprise architect should have direct input into the \\
business strategy process, because he understands the current \\
capabilities of the business and what it would take to build new \\
capabilities.
\end{tabular}

\subsection{Phase 3: Define style taxonomy}

The behavioural factors of an individual, and in this case the enterprise architect, is a fundamental component or psychosocial function as described by Bandura's social cognitive theory [4]. The two other psychosocial functions include personal factors (knowledge, expectations, attitudes) and environment influences (social norms, access in community, influences of others). The proximity of roles and competencies makes the association with behavioural factors (skills, practice, self-efficacy) fundamental to the understanding of the architect. Making use of the underlying theory and the electronic data collected from performing the online questionnaire, the architect style taxonomy was created based on the architect roles and personal competency characteristics [6].

Analysis of the EA behavioural styles questionnaire indicated the relationship between personal competency characteristics as defined by Bredemeyer and Malan [6], and Steghuis and Proper respectively [24]. Alignment of the five different positions on architect roles and the five different positions on architect competency classes, allowed 
for 25 theoretical architect behavioural styles. A 5X5 matrix, depicted in Figure 2, was used to represent the different architect behavioural styles.

Using the electronic data collected from the participants of the EA schools of thought [14] questionnaire on architect attributes, each participant was then placed in a specific architect behavioural style based on their understanding of their aligned architect roles and architect competencies. The data collected as part of EA schools of thought questionnaire on architect attributes and specifically the architects' answers on architect roles and architect competencies were used as the foundation for the understanding of the architect behavioural styles [6, 24]. Each of the answers from each of the architects was then viewed from the perspective of their specific architect behavioural style as their answers on their understanding of architect roles and competency. These answers on the architect attribute aligned questions provided insight into the understanding of the architect behavioural styles, in addition to the identification of the architect behavioural styles.

With the execution, collection and analysis of the data from the first research study, nine distinct architect behavioural styles were identified as viable from the 25 possible styles. An architect behavioural style was identified if it represented at least 5\% of the participating architect population. These nine architect behavioural styles represented $77 \%$ of the participating architects and were based on the participating enterprise architects' understanding of their architect roles and their architect competencies. Figure 2 illustrates the nine architecture behavioural styles representing at least $5 \%$ of the architect population.

\subsection{Phase 4: Enterprise architect behavioural style}

The focus of this research was on the architect and not what architecture or how architecting is being done. The identified enterprise architect behavioural styles include Disrupting technology, Translating technology, Innovation technology, Control technology, Directing strategy, Deciding strategy, Shifting advisory, Conversing advisory and Developing advisory behavioural style.

Architects from this study with a Disrupting technology, Directing strategy and Shifting advisory architect behavioural styles can be seen as change agents. Architects from this study with a Translating technology and Conversing advisory architect behavioural style can be seen as communicators. Architects from this study with an Innovating technology, Developing advisory and Deciding strategy architect behavioural style can be seen as leaders. Architects from this study with a Control technology architect behavioural style can be seen as managers. The different styles are summarized in Table 4. 


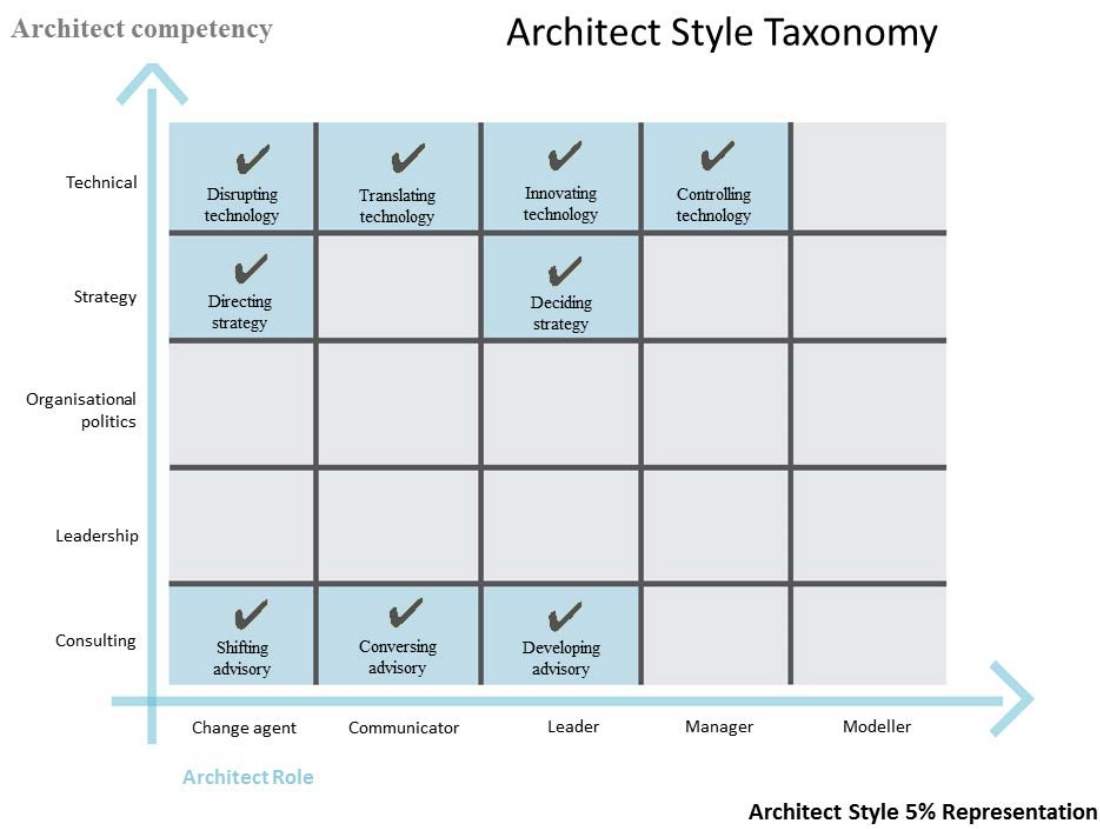

Figure 2: Enterprise architect behavioural styles as a construct

It is interesting to note that using a minimum of $5 \%$ representation in the study, indicated that architects generally did not see themselves or associate with the roles of leadership and organisational politics, in addition to also not associating with the competency of that of a modeller. Although the competency of modelling if a requirement for the position for an architect, the authors hypothesis that the specific competency of modelling is typically associated with the function of business analysts rather than that of architects.

As for the associated roles of leadership and organisational politics, the authors hypothesis that the function of architecture and that of being an architect stems from the disciplines of engineering and technology, where more technical skills and aptitudes are required rather than that of non-technical or soft skills. If the architects were from the disciplines of humanities, the authors' hypothesis that the leadership and organisational politics roles would have been better represented in the data. 
Table 4. Different behavioural styles

\begin{tabular}{|c|c|}
\hline $\begin{array}{l}\text { Behavioural } \\
\text { Style }\end{array}$ & Description \\
\hline \multicolumn{2}{|r|}{ Enterprise architect as change agent } \\
\hline \multirow{4}{*}{$\begin{array}{l}\text { Disrupting } \\
\text { technology }\end{array}$} & $\begin{array}{l}\text { Vision: Look for best technology strategy to accomplish technology goals [25]. } \\
\text {. }\end{array}$ \\
\hline & $\begin{array}{l}\text { Experience: Strong EA skills. } \\
\text { Educational background: Science degrees. }\end{array}$ \\
\hline & $\begin{array}{l}\text { Behavioural style regarding change: Inspire EA stakeholders to learn new things thorough } \\
\text { shared learning experiences [3]. }\end{array}$ \\
\hline & $\begin{array}{l}\text { Personal characteristics: Team players, good listeners, sometimes difficult to make } \\
\text { decisions [3], investigative, pragmatic, insightful, creative, investigative and tolerant of } \\
\text { ambiguity working at abstract system level [6], they value creativity, leadership, integrity, } \\
\text { openness, team work and opinion-forming personal characteristics. }\end{array}$ \\
\hline \multirow[t]{5}{*}{$\begin{array}{l}\text { Directing } \\
\text { Strategy }\end{array}$} & $\begin{array}{l}\text { Vision: Look for best organisational strategy to accomplish business goals and objectives } \\
\text { [25]. }\end{array}$ \\
\hline & $\begin{array}{l}\text { Experience: Senior EAs with over decade experience, work closely with other executives, } \\
\text { other architects and line managers. }\end{array}$ \\
\hline & Educational background: B degree with EA, technical and general IT skills. \\
\hline & $\begin{array}{l}\text { Behavioural style regarding change: Focus on uniting interests, stimulating EA } \\
\text { stakeholders to formulate opinions, creating mutually beneficial situations and forming } \\
\text { strategic coalitions [8]. Challenge other architects and EA stakeholders to move forward - } \\
\text { sometimes being insensitive [3]. }\end{array}$ \\
\hline & $\begin{array}{l}\text { Personal characteristics: They rely on their analytical, consulting, facilitation, verbal } \\
\text { communication and visualisation skills to apply their trade. They are visionary and have an } \\
\text { entrepreneurial perspective towards business strategy [6]. }\end{array}$ \\
\hline \multirow[t]{5}{*}{$\begin{array}{l}\text { Shifting } \\
\text { advisory }\end{array}$} & $\begin{array}{l}\text { Vision: Advise and support leaders in endorsing best organisational strategy to accomplish } \\
\text { business goals and objectives [25]. }\end{array}$ \\
\hline & $\begin{array}{l}\text { Behavioural style regarding change: Effective change agents, approachable, empathetic, } \\
\text { and committed to others' success, process savvy, good business skills, good mentors and } \\
\text { teachers [6]. }\end{array}$ \\
\hline & $\begin{array}{l}\text { Experience: Senior EA with less than decade experience, interact with analysts, architects } \\
\text { executives and project managers. }\end{array}$ \\
\hline & Educational background: Masters degree in sciences. \\
\hline & $\begin{array}{l}\text { Personal characteristics: They rely on their analytical, consulting, diplomacy, facilitation, } \\
\text { independence, listening, organisational awareness and written communication personal } \\
\text { competencies to execute their daily tasks [24]. Well-organised and predictable, but sometimes } \\
\text { slow to take basic ideas and realise them in practice [3]. }\end{array}$ \\
\hline \multicolumn{2}{|r|}{ Enterprise architect as leader } \\
\hline \multirow[t]{4}{*}{$\begin{array}{l}\text { Innovating } \\
\text { technology }\end{array}$} & $\begin{array}{l}\text { Vision: Create, motivate and give direction for a shared technology vision. Try to accomplish } \\
\text { technology goals and objectives to ensure technical performance improvements [25]. }\end{array}$ \\
\hline & Experience: Chief architects or at executive level and interact directly with executive \\
\hline & Educational background: Masters degree in professional or applied sciences \\
\hline & $\begin{array}{l}\text { Personal characteristics: Investigative, pragmatic, insightful, creative, investigative and } \\
\text { tolerant of ambiguity working at abstract system level [6]. }\end{array}$ \\
\hline \multirow[t]{4}{*}{$\begin{array}{l}\text { Deciding } \\
\text { strategy }\end{array}$} & $\begin{array}{l}\text { Vision: Create, motivate and give direction for a shared strategic vision. Provide direction on } \\
\text { how to execute technology strategy; Try to accomplish organisational goals and objectives to } \\
\text { ensure organisational performance improvements [25]. }\end{array}$ \\
\hline & $\begin{array}{l}\text { Experience: Senior enterprise architects, more than decade experience; interact with } \\
\text { executives and other architects. }\end{array}$ \\
\hline & Educational background: Masters/PhD. \\
\hline & $\begin{array}{l}\text { Personal characteristics: Visionary and entrepreneurial perspective towards business } \\
\text { strategy [6]. }\end{array}$ \\
\hline $\begin{array}{l}\text { Developing } \\
\text { advisory }\end{array}$ & $\begin{array}{l}\text { Vision: Create, motivate and give direction for a shared organisational vision. Provide } \\
\text { direction on how to execute business strategy; Try to accomplish organisational goals and } \\
\text { objectives to ensure organisational performance improvements [25]. }\end{array}$ \\
\hline
\end{tabular}




\begin{tabular}{|c|c|}
\hline & $\begin{array}{l}\text { Behavioural style regarding leadership: Effective consultants, approachable, empathetic, } \\
\text { and committed to others' success, process savvy, good business skills, good mentors and } \\
\text { teachers [14]. } \\
\text { Experience: Mid-level system architects, few years of EA experience, interact with } \\
\text { competency leads, analysts, other architects and project managers. } \\
\text { Educational background: post-secondary and non-tertiary education in a professional and } \\
\text { applied sciences discipline. } \\
\text { Personal characteristics: Generalists rather than specialists, using a variety of skills, } \\
\text { including business, consultancy skills, project management, general IT and technical IT } \\
\text { skills. Focus on bringing diverse interests together, encourage stakeholders to formulate } \\
\text { opinions, creating mutual beneficial situations and forming coalitions [8]. Reliable and see } \\
\text { tasks through to the end, eliminating concerns ensuring everything works well, although they } \\
\text { have a tendency to worry too much and not trusting others [3]. }\end{array}$ \\
\hline & Enterprise architects as communicators \\
\hline $\begin{array}{c}\text { Conversing } \\
\text { advisory }\end{array}$ & $\begin{array}{l}\text { Vision: Assist others to understand technology strategy to ensure realisation of shared vision. } \\
\text { Behavioural style regarding communication: Effective consultants, approachable, } \\
\text { empathetic, and committed to others' success, process savvy, good business skills, good } \\
\text { mentors and teachers [25]. } \\
\text { Experience: Senior enterprise architects with less than decade EA experience, interact with } \\
\text { executives and line managers. } \\
\text { Educational background: Masters' degree in formal sciences. } \\
\text { Personal characteristics: Generalists rather than specialists, focussing on the natural flow of } \\
\text { people's interests and processes and are concerned with efficiency [8]; Analytical, persuasive, } \\
\text { result driven, and work well in teams; See big picture, but may lack ability to inspire others } \\
\text { [3]. }\end{array}$ \\
\hline $\begin{array}{l}\text { Translating } \\
\text { technology }\end{array}$ & $\begin{array}{l}\text { Vision: Assist others to understand technology strategy to ensure realisation of shared vision. } \\
\text { Experience: Senior architects with } 10-15 \text { years of EA experience, work closely with } \\
\text { executives, project managers and other architects. } \\
\text { Educational background: Bachelor's degree in professional and applied sciences. } \\
\text { Personal characteristics: Investigative, pragmatic, insightful, creative, investigative and } \\
\text { tolerant of ambiguity working at abstract system level }\end{array}$ \\
\hline & Enterprise architect as manager \\
\hline $\begin{array}{c}\text { Control } \\
\text { technology }\end{array}$ & $\begin{array}{l}\text { Vision: They organise the architecture team whilst ensuring adequate resources are available } \\
\text { to perform the enterprise architecture management process [25]; Tasks include to formulate } \\
\text { unambiguous technology objectives, develop action plan, monitor and adjust the technology } \\
\text { change process [8]. } \\
\text { Experience: Often limited EA experience but good IT skills } \\
\text { Educational background: Masters degree with general IT skills } \\
\text { Personal characteristics: great organisational awareness, strong persuasiveness, result } \\
\text { driven, self-confident, have good written communication skills, work well within teams [24]; } \\
\text { Investigative, pragmatic, insightful, creative, investigative and tolerant of ambiguity working } \\
\text { at [6]; They can be poor at communicating and may ignore relevant details [3]. }\end{array}$ \\
\hline
\end{tabular}

\section{Conclusion}

A concern exists that no universal understanding exists of what exactly EA is. As a result of the lack of universal understanding, certain limitations become relevant in the teaching and training of future architects as well as the universally adopted EA frameworks, definitions, methodologies and techniques. Rather than trying to obtain consensus of EA concepts, this research focused on the understanding of enterprise architect profiles by suggesting nine different architectural behaviour styles. Currently research is conducted to establish the value of the styles in selection of architecture teams. 


\section{References}

1. Aier, S., Schelp, A.: A reassessment of enterprise architecture implementation. In: Service-Oriented Computing. ICSOC/ServiceWave. pp. 35-47 Springer (2009).

2. Akenine, D.: A Study of Architect Roles by IASA Sweden. Archit. J. 15, (2008).

3. Aritzeta, A. et al.: Belbin's Team Role Model: Development, Validity and Applications for Team Building. J. Manag. Stud. 44, 1, 96-118 (2007).

4. Bandura, A., National Inst of Mental Health.: Prentice-Hall series in social learning theory. Social foundations of thought and action: A social cognitive theory. Pentrice-Hall, Inc, Englewood Cliffs, NJ, US.

5. Bernus, P., Nemes, L.: A framework to define a generic enterprise reference architecture and methdology. Comput. Integr. Manuf. Syst. 9, 179-191.

6. Bredemeyer, D., Malan, R.: What it takes to be a great enterprise architect. Enterprise Architecture-Cutter Consortium (2015).

7. Buckl, S. et al.: State of the Art in Enterprise Architecture Management. (2009).

8. De Caluwe, L., Vermaak, H.: Learning to Change: A Guide for Organization Change Agents. SAGE Publications, Inc., 2455 Teller Road, Thousand Oaks California, USA (2003).

9. Du Preez, Jaco et al.: Enterprise Architecture School of Thought: An Exploratory Study,. Presented at the IEEE Enterprise Distributed Object Computing Conference Workshops and Demonstrations, Ulm, Germany (2014).

10. Du Preez, Jaco: Understanding the architect in enterprise architecture: the Daedulus Instrument for architects. University of Pretoria (2016).

11. Gotze, J.: The Changing Role of the Enterprise Architect. Presented at the September (2013).

12. Kitchenham, B.: Procedures for performing systematic reviews. (2004).

13. Lankhorst, M.: Enterprise architecture at work: Modelling, communication and analysis. Springer Verlag, New York (2009).

14. Lapalme, J.: Three Schools of Thought on Enterprise Architecture. IT Prof. 14, 6, 37-43 (2012).

15. Lu, H., Lin, P.: A study of competence of enterprise architects in higher education. In: Proceedings of 2012 IEEE 3rd International Conference on Software Engineering and Service Science. pp. 551-554 (2012).

16. Mentz, J.: Enterprise architectonics as a conceptual device to support a fundamental understanding of enterprise architecture. UNISA, University of South Africa (2014).

17. Mentz, J. et al.: Propositions that describe the intended meaning of Enterprise Architecture. In: South African Institute of Computer Scientists and Information Technologists (SAICSIT) Conference. , Leriba Lodge, Centurion (2014).

18. Mian, P. et al.: A systematic review process for software engineering, http://www.lbd.dcc.ufmg.br/colecoes/eselaw/2005/009.pdf.

19. OpenGroup: TOGAF, http://www.opengroup.org/, (2018).

20. Ouriaghli, A., Nsubuga, W.: GUPEA: Enterprise Architect's Roles in a Proactive Enterprise Development Context - PED model for understanding the role of an Enterprise Architect in a Proactive Enterprise Development context, https://gupea.ub.gu.se/handle/2077/30798?locale=sv. 
21. Ross, J. et al.: Enterprise architecture as strategy: Creating a foundation for business execution. Harvard Business School Press (2006).

22. Schöenherr, M.: Towards a Common Terminology in the Discipline of Enterprise Architecture. In: Feuerlicht, G. and Lamersdorf, W. (eds.) Service-Oriented Computing - ICSOC 2008 Workshops. pp. 400-413 Springer Berlin Heidelberg, Berlin, Heidelberg (2009).

23. van Steenbergen, M. et al.: Achieving Enterprise Architecture Benefits: What Makes the Difference? Presented at the August (2011).

24. Steghuis, C., Proper, E.: Competencies and Responsibilities of Enterprise Architects. In: Dietz, J.L.G. et al. (eds.) Advances in Enterprise Engineering I. pp. 93-107 Springer Berlin Heidelberg, Berlin, Heidelberg (2008).

25. Strano, C., Rehmani, Q.: The role of the enterprise architect. Inf. Syst. E-Bus. Manag. 5, 4, 379-396 (2007). 